\title{
PENGORGANISASIAN NANG NING NUNG NENG GUNG PADA GAMELAN JAWA SEBAGAI KAJIAN FILOSOFIS DALAM PENGAJARAN BAHASA INGGRIS
}

\author{
Sulistiyani ${ }^{1}$, Fransisca R. Sunarmi ${ }^{2}$, Siti Fatimah ${ }^{3}$ \\ 1,2,3 STKIP Bina Insan Mandiri \\ Correspondence Email: sulis_yy21@gmail.com
}

Received: Jan 25, 2020 Revised: Jan 29, $2020 \quad$ Accepted: Feb 4, 2020

\begin{abstract}
ABSTRAK
Keberadaan gamelan di STKIP Bina Insan Mandiri digunakan sebagai simbol hidup bermasyarakat. Dengan memaknai bunyi gamelan sebagai pedoman hidup bebrayan agung dan mengajarkannya dalam Bahasa Inggris dapat memudahkan pelajar dan masyarakat untuk mengetahui cara penulisan dan cara membaca bahasa Inggris dengan baik, serta untuk meningkatkan ketertarikan pelajar dan masyarakat tentang pembelajaran bahasa Inggris dengan berbasis pengorganisasian dalam pemaknaan filosofis pada gamelan. Tujuan penelitian diantaranya untuk membangun sebuah pembelajaran bahasa Inggris berbasis pengorganisasian pada bunyi yang dihasilkan pada gamelan Jawa dan pemaknaannya. Metode penelitian ini menggunakan penelitian kualitatif deskriptif, dimana yang menjadi subjek penelitian ini adalah mahasiswa STKIP Bina Insan Mandiri yang berjumlah sebanyak 120 mahasiswa. Penelitian dimulai dari observasi, wawancara dengan ketua, dosen, karyawan/staf dan mahasiswa. Pengumpulan data dalam penelitian ini menggunakan metode observasi, wawancara dan dokumentasi. Adapun Teknik analisis data yang digunakan adalah reduksi data, display data dan verifikasi data.

Hasil penelitian pada studi tersebut yakni, cara implementasi pembelajaran bahasa Inggris berbasis Kajian Nang Ning Nung Neng Gung dengan pengaplikasian pendekatan tiga pola yaitu pola pembiasaan/pengulangan, pola contoh, dan pola implementasi dan pengorganisasian serta pemahaman pada pedoman hidup dalam hidup bebraian agung.
\end{abstract}

Kata kunci: Pengorganisasian Nang Ning Nung Neng Gung, Gamelan Jawa, Pembelajaran Bahasa Inggris

\begin{abstract}
The existence of gamelan in STKIP Bina Insan Mandiri is used as a symbol of social life. The purpose of the research is to build an English learning based on the organization of the sounds produced in Javanese gamelan and their meanings. By interpreting, the sound of gamelan as a guide to the great bebrayan life and teaching it in English, it will make it easier for students and the public to know how to write and read English well, as well as increase students and community interest in organizing-based English learning in the philosophical meaning of gamelan. The research method is descriptive qualitative research,
\end{abstract}


where the subjects of this research are STKIP Bina Insan Mandiri students, totaling 120 students. The qualitative research started from observations, interviews with the chairperson, lecturers, employees/staff, and students. Collecting data in this study was using the method of observation, interviews and documentation. The data analysis techniques used are the data reduction, data the display and the data verification.

The result of this research, how to implement English language learning based on the Nang Ning Nung Neng Gung Study by applying a three-pattern approach, namely the habituation/repetition pattern, the example pattern, and the implementation and organization pattern as well as an understanding of the guidelines for living in the great bebrayan life.

Keywords : Organizing Nang Ning Nung Neng Gung, Javanese Gamelan, English Learning

\section{INTRODUCTION}

Dunia memang sedang tergoncang oleh kasus corona virus disease atau dikenal dengan istilah covid-19 sejak akhir tahun lalu. Dengan adanya virus corona tersebut mengakibatkan perubahan sistem yang ada di dunia pendidikan termasuk di Indonesia. Pendidikan sangat erat kaitannya dengan pengoorganisasian beberapa aspek yang ada didalamnya. Diantaranya yakni kesinambungan dalam mengisi dan memaknai konteks yang diajarkan khususnya dalam pembelajaran Bahasa Inggris. Penelitian Ini dilatarbelakangi pada observasi yang dilakukan di STKIP Bina Insan Mandiri.

Pada observasi tersebut menemukan bahwa di STKIP Bina Insan Mandiri keberadaan gamelan digunakan sebagai simbol karakteristik bangsa dan pedoman hidup bebrayan agung. Melalui pengorganisasian Nang Ning Nung Neng Gung pada alunan gamelan Jawa. Sehingga dengan adanya simbol dan karakter yang kuat, diharapkan masyarakat tetap berpegang teguh pada norma dan nilai luhur budaya khususnya budaya masyarakat Jawa. Sebagai Sekolah Tinggi Keguruan dan Ilmu Pendidikan STKIP Bina Insan Mandiri khususnya prodi Pendidikan Bahasa Inggris berani melangkah untuk menjadikan pembelajaran online sebagai salah satu kesempatan mentransformasi pendidikan di tengah pandemi ini.

Adapun minat dan perhatian para mahasiswa terhadap materi pelajaran yang akan disajikan hendaknya disusun secara logis dan praktis sehingga para mahasiswa dapat mengenal, mengingat dan memikirkan serta mengaplikasikan secara baik. Kemampuan siswa dalam berfikir dan dapat menggunakan keilmuan tersebut dalam situasi transfer of learning. Salah satu situasi yang dikondisikan yaitu belajar berlangsung dari yang sederhana meningkat kepada yang kompleks. Keberadaan 
gamelan di STKIP Bina Insan Mandiri digunakan sebagai simbol hidup bermasyarakat. Tujuan penelitian adalah membangun sebuah pembelajaran bahasa Inggris berbasis pengorganisasian pada bunyi yang dihasilkan pada gamelan Jawa dan pemaknaannya.

Metode pembelajaran yang dilakukan oleh pendidik tidak hanya menggunakan ceramah, dalam pengajaran sehingga pembelajaran tidak bersifat menoton. Strategi dalam pembelajaran merupakan pola umum yang digunakan untuk mewujudkan dalam proses pembelajaran yang diyakini efektivitasnya untuk mencapai tujuan pembelajaran. Majid (2013:8) yang menyatakan bahwa strategi pembelajaran merupakan suatu rencana atau tindakan yang termasuk dalam penggunaan metode dan pemanfaatan berbagai sumber daya dalam pembelajaran. Beberapa contoh penggunaan metode dalam pembelajaran antara lain metode ceramah, demonstrasi, diskusi, simulasi, laboratorium, pengalaman lapangan, debat dan simposium (Majid, 2013:22).

Adapun media pembelajaran yang digunakan juga sangat menunjang pemahaman siswa dalam kegiatan pembelajaran.Arsyad (2014:2) menyatakan bahwa, media merupakan bagian yang tidak terpisahkan dari proses belajar mengajar demi tercapainya tujuan pendidikan pada umumnya dan pembelajaran. Menurut Sukmadinata (2003:112-124), media pembelajaran dapat diartikan sebagai sesuatu yang digunakan menyalurkan pada isi pembelajaran, merangsang pikiran, perasaan, perhatian dan mendorong kemampuan siswa dalam proses belajar mengajar.

Sebagai Sekolah Tinggi Keguruan dan Ilmu Pendidikan, STKIP Bina Insan Mandiri merupakan wadah pencetak calon guru sebagai pendidik bangsa. Pada STKIP pendidikan karakter sangat ditekankan dalam penerapannya. Salah satu diantaranya dengan praktek secara langsung yakni mendengarkan dan memahami makna pada bunyi gamelan. Bunyi yang dihasilkan dari gamelan tersebut mengandung makna filosofis.

Di awal abad ke 21 ini cukup sulit dalam menemukan pendidikan yang mempelajari tentang keunggulan budaya masing-masing daerah. STKIP Bina Insan Mandiri merupakan salah satu contoh kampus yang masih mempertahankan keunggulan budaya lokalnya salah satunya yaitu seni gamelan jawa. Kesenian gamelan Jawa merupakan kesenian asli masyarakat Jawa. Namun dalam Implementasi pendidikan keunggulan lokal pada gamelan Jawa yakni pada kajian 
filosofis bunyi Nang Ning Nung Neng Gung yang mengandung makna dalam pedoman hidup bebrayan agung.

Ditengah banyaknya kampus. STKIP Bina Insan Mandiri merupakan kampus yang mencetak calon guru sebagai pendidik bangsa. Adapun program studi yang ada di STKIP Bina Insan Mandiri yakni Pendidikan Matematika, Pendidikan Bahasa Indonesia, PGSD, PGPAUD, dan Pendidikan Bahasa Inggris. Pembelajaran Bahasa Inggris juga menjadi mata pelajaran wajib di setiap program studi karena masuk pada kurikulum KKNI pada perguruan tinggi.

Pembelajaran Bahasa Inggris yang disajikan di STKIP Bina Insan Mandiri sudah sangat baik, namun hanya mengacu kepada materi pembelajaran yang merujuk pada RPP dan silabus dengan target penguasaan Bahasa yang tepat sasaran. Tidak jauh dengan kampus lain, yang dipelajari hanya berfokus pada silabus dan buku pedoman pendidikan yang isinya bertemakan global dan teknologi sebagai acuan Bahasa sasaran. Dimana poin dari pembelajaran Bahasa Inggris tersebut yakni kelancaran conversation pada keberhasilan capaian sangat diharapkan.

\section{METODE}

\section{Jenis Penelitian}

Jenis penelitian yang digunakan dalam penelitian gamelan Jawa ini adalah jenis penelitian kualitatif deskriptif. Penelitian kualitatif tersebut merupakan penelitian yang menggunakan latar belakang ilmiah dengan maksud menafsirkan fenomena yang terjadi dan dilakukan dengan melibatkkan berbagai metode yang ada. Penelitian kualitatif yakni penelitian yang memanfaatkan wawancara terbuka untuk menelaah dan memahami sikap, pandangan, perasaan pada prilaku individu atau kelompok orang Pendekatan pada penelitian kualitatif lebih banyak menggunakan logika hipotetiko verifikatif. Pendekatan tersebut dimulai dengan pola berpikir deduktif untuk menurunkan hipotesis tersebut ditarik berdasarkan data empiris. Dengan demikian penelitian kualitatif tersebut lebih menekankan pada indeks-indeks dan pengukuran empiris

Analisis yang digunakan dalam penelitian kualitatif lebih bersifat deskriptif-analitik yang berarti interpretasi terhadap isi dibuat dan disusun secara sistemik/ menyeluruh dan sistematis. 


\section{Subjek Penelitian}

Subjek penelitian yang dimaksud peneliti adalah pihak- pihak yang secara langsung terkait dan berkompeten dalam Implementasi pada pembelajaran Bahasa Inggris khususnya dalam pengorganisasian alunan nada yang berbasis Kajian filosofi gamelan Jawa di STKIP Bina Insan Mandiri serta sumber- sumber yang berhubungan dengan penelitian. Subjek penelitian ini diarahkan pada pihak- pihak masyarakat kampus dan orang- orang atau lembaga yang berperan dalam pembelajaran budaya lokal. Penentuan sampel dalam penelitian kualitatif tersebut tidak didasarkan kepada statistik, sampel yang dipilih untuk mendapatkan informasi yang maksimum bukan digeneralisasikan.

\section{Sumber data Penelitian}

Data yang diambil dalam penelitian ini berasal dari kampus STKIP Bina Insan Mandiri Yang menjadi sample penelitian. Untuk mendapatkan sumber data yang tepat dan akurat.

\section{Teknik Pengumpulan dan Analisis Data}

Untuk memperoleh data, penelitian ini menggunakan metode- metode berikut ini:

\section{Observasi}

Observasi merupakan suatu proses yang kompleks, suatu proses yang tersusun dari berbagai proses biologis dan psikologis. Antara biologis dan psikologis merupakan dua diantara yang paling penting adalah proses pengamatan. Teknik pengumpulan data dengan observasi yang digunakan bila, penelitian berkenaan dengan prilaku manusia, proses kerja dan gejala alam Observasi tersebut merupakan teknik pengamatan dan pencatatan secara sistematis dari fenomena-fenomena yang diselidiki. Observasi tersebut dilakukan untuk menemukan data atau informasi dari gejala atau fenomena (kejadian atau peristiwa) secara sistematis dan berdasarkan pada tujuan penyelidikan yang telah dirumuskan.

\section{Wawancara}

Wawancara tersebut merupakan suatu alat pengumpul data atau informasi yang dilakukan dengan cara mengajukan pertanyaan lisan dan dijawab secara lisan pula. Wawancara tersebut digunakan sebagai teknik pengumpulan data untuk mendapatkan informasi yang lebih dalam tentang responden. Wawancara 
tersebut dapat dilakukan secara langsung maupun tidak langsung dengan sumber data dan dilakukan tanpa menggunakan perantara baik tentang dirinya maupun tentang segala sesuatu yang berhubungan dengan dirinya untuk mengumpulkan data yang telah diperlukan.

\section{Dokumentasi}

Dokumentasi merupakan salah satu teknik pengumpulan data yang tidak langsung ditunjukkan pada subjek penelitian tetapi melalui dokumen. Dokumen tersebut merupakan catatan tertulis yang isinya merupakan pernyataan tertulis yang disusun oleh seseorang atau lembaga untuk keperluan pengujian pada suatu peristiwa dan berguna bagi sumber data, bukti, informasi kealamiahan yang sulit untuk ditemukan dan membuka kesempatan untuk lebih memperluas pengetahuan terhadap sesuatu yang diselidiki.

\section{Pembahasan}

Sebagian besar dari orang jawa khususnya, nada yang keluar dari gamelan merupakan nada yang dijadikan alat untuk pemujaan dan perenungan spiritual yang dalam. Nada - nada dalam musik gamelan dinilai bukan sekedar seni, tetapi merupakan bahasa jiwa, spirit kehidupan, musik Sang Maha Pencipta, bahasa pertama yang menjadi asal muasal kehidupan. Sebagai salah satu media dan bentuk komunikasi universal, nada-nada musik melewati bahasa verbal, diterima indera pendengaran, diteruskan ke hati, dan diproses ke dalam pusat rasa.

Penalaan dan atau pengorganisasian dan pembuatan orkes gamelan merupakan suatu proses yang kompleks. Gamelan menggunakan empat cara penalaan, yaitu sléndro, pélog, dan degung (khusus daerah Jawa Barat), dan madenda (juga dikenal sebagai diatonis, sama seperti skala minor asli yang umumnya banyak dipakai di Eropa. Musik gamelan Jawa merupakan gabungan pengaruh seni luar negeri yang beraneka ragam. Kaitan not atau nada dari Cina, instrumen musik dari Asia Tenggara, drum band dan gerakkan musik dari India, bowed string dari daerah Timur Tengah, bahkan style militer Eropa yang kerap di dengar pada musik tradisional Jawa dan Bali sekarang ini.

Hasil dari penelitian ini dapat dirumuskan upaya pelestarian budaya bangsa melalui alunan gamelan Jawa yang berkontribusi pada pengembangan pengetahuan, keterampilan, dan nilai-nilai dasar yang direfleksikan dalam kebiasaan berfikir dan bertindak dalam mengisi urip bebrayan. Kebiasaan berfikir 
dan bertindak secara konsisten dan terus menerus memungkinkan seseorang menjadi kompeten, dalam arti memiliki pengetahuan, keterampilan, dan nilai-nilai dasar untuk melakukan sesuatu dan diimplikasikan kedalam perilaku sehari-hari dalam menjalani hidup dan kehidupan sehingga bisa mencetak generasi bangsa yang berkualitas baik dalam segi intelektual, kepribadian dan bermanfaat dengan kepribadian yang baik di masa depan

\section{B. KESIMPULAN}

Berdasarkan hasil pembahasan dari penelitian diatas, maka dapat mengambil kesimpulan sebagai berikut:

Suasana Pembelajaran di STKIP Bina Insan Mandiri mengimplementasikan pedoman urip bebrayan agung melalui kajian filosofis dalam pengorganisasian Nang Ning Nung Neng Gung ke dalam pembelajaran Bahasa Inggris untuk membentuk suatu karakter dan kebiasaan berpraktek Bahasa Inggris secara langsung.

Implementasi pada pembelajaran berbasis Kearifan Lokal sangat penting jika diterapkan di sekolah tinggi ini karena merupakan suatu kesatuan dan kebutuhan sebagai pelopor. Pembelajaran Bahasa Inggris yang diterapkan melalui tema-tema pembelajaran dalam teks, seperti narrative text, descriptive text dan lain-lain dengan menggunakan teks yang berasal dari budaya sendiri, Juga bisa diterapkan dengan vocabulary enhancement dengan membuat kosakata dan mempraktekkannya. Bisa juga degan cara menyelipkan instruksi berbahasa Inggris dalam pembelajaran seni gamelan Jawa lewat kegiatan ekstra kurikuler.

Penerapan kajian ini juga diharapkan bisa memajukan dalam memotivasi mahasiswa agar lebih semangat lagi dalam belajar Bahasa Inggris, Sehingga dapat mempermudah pembelajaran dan membudayakan budaya lokal yang berada di lingkungan Sekolah Tinggi Keguruan dan Ilmu Pendidikan Bina Insan Mandiri tersebut. 


\section{DAFTAR PUSTAKA}

Arsyad,Hidayat, asep ahmad. (2014) Filsafat bahasa: Mengungkap hakikat bahasa, makna dan tanda. Bandung. PT Remaja Rosdakarya.

Brown, Douglas. (2007) Teaching by Principles: An Interactive Approach to Language Pedagogy. United State of America: Pearson.

Majidhali, Imam, dan Ara Hidayat. (2013) The Handbook of Education Management : Teori dan Praktek Pengelolaan Sekolah/Madrasah di Indonesia. Jakarta: Prenadamedia Group.

Margana. (2009). Integrating local culture into English Teaching and Learning process.Linguistik dan Sastra, vol 21, no.2.

Mulyasa. (2010) Menjadi Guru Professional Menciptakan Pembelajaran Kreatif dan Menyenangkan. Bandung: Rosda.

Rivai, Veithzal. (2004) Kepemimpinan dan Perilaku Organisasi. Jakarta: PT RajaGrafindo Persada.

Robbins, Stephen P. (1996) Perilaku Organisasi : Konsep, Kontroversi dan Aplikasi. Dialihbahasakan oleh Hadyana Pujaatmaka. Vol. I. Jakarta: PT Prenhallindo.

-. Perilaku Organisasi: Konsep, Kontroversi dan Aplikasi. Dialihbahasakan oleh Hadyana Pujaatmaka. Vol. II. Jakarta: PT Prenhallindo.

Sukmadinata, Sardjiyo dan Pannen, P. (2003) "Pembelajaran Berbasis Budaya: Model Inovasi Pembelajaran dan Implementasi Kurikulum Berbasis Kompetensi.” Jurnal Pendidikan. $6(2)$

Saud, Udin Syaefudin. (2012) Inovasi Pendidikan. Bandung: Alfabeta.

Sagala, Syaiful. (2012) Administrasi Pendidikan Kontemporer. Bandung: Alfabeta.

Sugiyono. (2013) Metode Penelitian Manajemen. Bandung: Alfabeta.

Sutisna, Oteng. Administrasi Pendidikan : Dasar Teoretis untuk Praktek Profesional. Bandung : Angkasa, 1989.

UPI, Tim Dosen Administrasi Pendidikan. (2013) Manajemen Pendidikan. Bandung: Alfabeta. 